\title{
Study on the dimensional stability of modern impression materials
}

\author{
Studiu asupra stabilităţii dimensionale a materialelor de amprentă moderne
}

\section{Bogdan Mihai Gălbinașu', Marin-Lucian Dragason², Vlad-Cristian Grigore³, Lucian Toma Ciocan', Ion Pătrașcu' ${ }^{1}$}

\author{
${ }^{1}$ Catedra de Tehnologia Protezelor și Materiale Dentare, Facultatea de Medicină Dentară, \\ Universitatea de Medicină și Farmacie „Carol Davila“, București, România \\ ${ }^{2}$ Institutul de Studii Universitare de Doctorat al Universităţii „Lucian Blaga“, Sibiu, România \\ ${ }^{3}$ Rezidenţiat, București, România
}

\begin{abstract}
Objective. Comparative evaluation of the accuracy and dimensional stability of modern impression materials, given that often the casting is not done at a short interval after impression.

Materials and methods. 4 modern impression materials were studied as follows: alginate (Tropicalgin-Zhermack), condensing silicone (Speedex-Coltene), addition silicone (Elite-Zhermack) and polyether (Impregum-3M/ESPE). With each of them was taken an impression of the same occlusal surface of an extracted molar, using a monophase technique. Both the control and the samples of impression materials obtained were subjected to stereomicroscopy investigations. Each sample was analyzed immediately (one hour after the impression), one day, 3 days and 7 days after the impression, respectively, taking the same reference marks for measurements identical to those on the control sample. Following the analysis, the dimensional variation of the analyzed materials compared to the control sample could be measured. The thickness of an enamel ridge bordered by two imagistically obvious ditches was taken as a reference.

Results. Alginate suffers the greatest contraction at 24 hours (1.94\%), but also at 7 days $(0.91 \%)$. Addition silicones have the lowest shrinkage at 24 hours $(0.03 \%)$ and polyethers the smallest variation over time $(0.25 \%$ at 24 hours and $0.53 \%$ at 7 days). The polyethers also show the highest accuracy, the initial value $(2,799 \mu \mathrm{m})$ being the closest to the value of the control sample $(2,805 \mu \mathrm{m})$.

Conclusions. All the impression materials studied undergo dimensional variations, the maximum contraction being in the first 24 hours, followed by a slight expansion due to postpolymerization de-stressing. Addition silicones show the lowest volumetric variation one day after registration, and polyethers 7 days after. Polyethers have the highest accuracy, while irreversible hydrocolloids have major dimensional changes and low accuracy compared to other materials.
\end{abstract}

Keywords: impression materials, irreversible hydrocolloids, silicones, polyethers, stability

\section{REZUMAT}

Obiectiv. Evaluarea comparativă a fidelității şi stabilităţii dimensionale a materialelor de amprentă moderne, având în vedere că de multe ori turnarea modelelor de lucru nu se realizează la un interval scurt după amprentare. Material şi metodă. Au fost luate în studiu 4 materiale de amprentă moderne, după cum urmează: alginat (Tropicalgin-Zhermack), silicon de condensare (Speedex-Coltene), silicon de adiţie (Elite-Zhermack) şi polieter (Impregum3M/ESPE). Cu fiecare dintre ele s-a amprentat prin tehnica într-un singur timp aceeaşi suprafaţă ocluzală a unui molar de minte extras. Atât martorul, cât şi probele de materiale de amprentă obţinute au fost supuse investigaţiilor de stereomicroscopie. Fiecare probă a fost analizată imediat (la o oră după amprentare), la o zi, 3 zile şi, respectiv, 7 zile de la amprentare, luându-se aceleaşi repere de referinţă pentru măsurători identice cu cele de pe proba martor. În urma analizei, a putut fi măsurată variaţia dimensională a materialelor analizate faţă de proba martor. S-a luat ca reper grosimea unei creste de smalţ, mărginită de două şanţuri evidente imagistic.

Rezultate. Alginatul suferă cea mai mare contracţie la 24 de ore $(1,94 \%)$, dar şi la 7 zile $(0,91 \%)$. Siliconii de adiţie prezintă cea mai redusă contracţie la 24 de ore $(0,03 \%)$, iar polieterii prezintă cea mai mică variaţie în timp $(0,25 \%$ la 24 de ore şi $0,53 \%$ la 7 zile). Polieterii prezintă, de asemenea, cea mai mare fidelitate, valoarea iniţială $(2.799 \mu \mathrm{m})$ fiind cea mai apropiată de valoarea probei martor $(2.805 \mu \mathrm{m})$.

Concluzii. Toate materialele de amprentă luate în studiu suferă variaţii dimensionale, contracţia maximă fiind în primele 24 de ore, urmând o uşoară dilatare datorată detensionării postpolimerizare. Siliconii de adiție prezintă cea mai redusă variaţie volumetrică la o zi de la înregistrare, iar polieterii la 7 zile. Cea mai mare acurateţe o prezintă polieterii, în timp ce hidrocoloizii ireversibili prezintă modificări majore ale dimensiunilor şi acurateţe redusă faţă de celelalte materiale.

Cuvinte cheie: materiale de amprentă, hidrocoloizi ireversibili, siliconi, polieteri, stabilitate 


\section{INTRODUCERE}

Înregistrarea amprentei reprezintă o parte esenţială în procesul de obţinere a restaurărilor indirecte prin transferul către laborator al poziţiei, dimensiunilor şi chiar al consistenţei ţesuturilor dure şi moi ale cavităţii orale. Astfel, cunoaşterea exactă a anatomiei, alegerea materialelor de amprentă şi a tehnicilor optime sunt decisive pentru o amprentare corectă şi fidelă şi, implicit, o lucrare protetică perfect adaptată [1].

Materialele de amprentă sunt un factor fundamental în procesul complex de amprentare. Stabilitatea dimensională şi fidelitatea reproducerii detaliilor sunt cele mai importante caracteristici ale acestora, ghidând medicul stomatolog în alegerea materialului optim pentru fiecare situaţie clinică. De asemenea, rezistența la substanţele dezinfectante şi lipsa modificărilor de consistenţă şi dimensiune în timpul stocării sunt deziderate importante pe care trebuie să le îndeplinească materialele [2-4]. Nicholls [5] indică faptul că stabilitatea dimensională induce capacitatea materialului de amprentă de a-şi menţine acurateţea redării detaliilor, astfel că denaturarea sa implică pierderea fidelităţii şi poate duce la deformare permanentă.

Ulterior înregistrării amprentei, se realizează turnarea modelului pe baza căruia se fabrică restaurările indirecte. Perioada de stocare a amprentei până la turnarea modelului are implicaţii majore asupra calităţilor materialului, cu precădere asupra stabilităţii dimensionale. Cele mai mici modificări ale proprietăţilor s-au obţinut prin turnarea imediată a modelului, însă în practică acest aspect este dificil de realizat din cauza timpului necesar trimiterii amprentei către laborator [6,7].

În prezent, materialele de amprentă cel mai frecvent utilizate sunt hidrocoloizii şi elastomerii, indicaţia variind cu situaţia clinică [8]. În situaţiile în care modelul nu se poate turna într-un timp foarte scurt, siliconii de adiţie şi polieterii reprezintă alegerea optimă datorită stabilităţii dimensionale superioare în timp [9]. Siliconii de condensare prezintă, de asemenea, o structură asemănătoare cu cei de adiţie, având însă o deformare în timp superioară [6]. Folosiţ̧i pe scară largă, hidrocoloizii ireversibili (alginat) nu pot fi utilizaţi pentru amprente de precizie, precum cele finale pentru coroane sau punţi, din cauza modificărilor dimensionale importante ce survin la 10 minute de la îndepărtarea amprentei din cavitatea orală [10].

Aşadar, scopul prezentului studiu este de a evalua comparativ fidelitatea şi stabilitatea dimensională a materialelor de amprentă moderne, având în vedere că, de multe ori, turnarea modelelor de lucru nu se realizează la un interval scurt după amprentare. Mai mult decât atât, producătorul materialelor de amprentă siliconice nu face referire la timpul în care modelul ar trebui turnat.

\section{MATERIALE ŞI METODE}

$\mathrm{Au}$ fost luate în studiu 4 materiale de amprentă moderne, după cum urmează: alginat (TropicalginZhermack), silicon de condensare (Speedex-Coltene), silicon de adiție (Elite-Zhermack) şi polieter (Impregum-3M/ESPE) (Fig. 1).

$\mathrm{Cu}$ fiecare dintre ele s-a amprentat prin tehnica într-un singur timp aceeaşi suprafaţă ocluzală a unui molar de minte extras (Fig. 2).

Atât martorul, cât şi probele de materiale de amprentă obţinute (Fig. 3) au fost supuse investigaţiilor de stereomicroscopie, în cadrul colaborării cu Facultatea de Ştiinţa şi Ingineria Materialelor din cadrul Universităţii Politehnice Bucureşti.

Probele au fost analizate utilizând o linie de analiză de imagine compusă din stereomicroscop Reichert, camera specializată de achiziţie imagini (Polaroid) şi software de analiză de imagine Buehler Omnimet. Imaginile stereomicroscopice au fost preluate utlizând o lentilă planapocromată $(1,5 \mathrm{X})$. Calibrarea imaginilor a fost efectuată utilizând o scală micronică cu ajutorul soft-ului de analiză cantitativă.

Fiecare probă a fost analizată imediat (la o oră după amprentare), la o zi, 3 zile şi, respectiv, 7 zile de la amprentare, luându-se aceleaşi repere de referinţă pentru măsurători identice cu cele de pe proba martor.

În urma analizei, a putut fi măsurată variaţia dimensională a materialelor analizate faţă de proba martor. S-a luat ca reper grosimea unei creste de smalţ, mărginită de două şanţuri evidente imagistic. Reperul a putut fi identificat pe toate probele analizate. Astfel, măsurătoarea pentru proba martor a fost de $2.805 \mu \mathrm{m}$. 


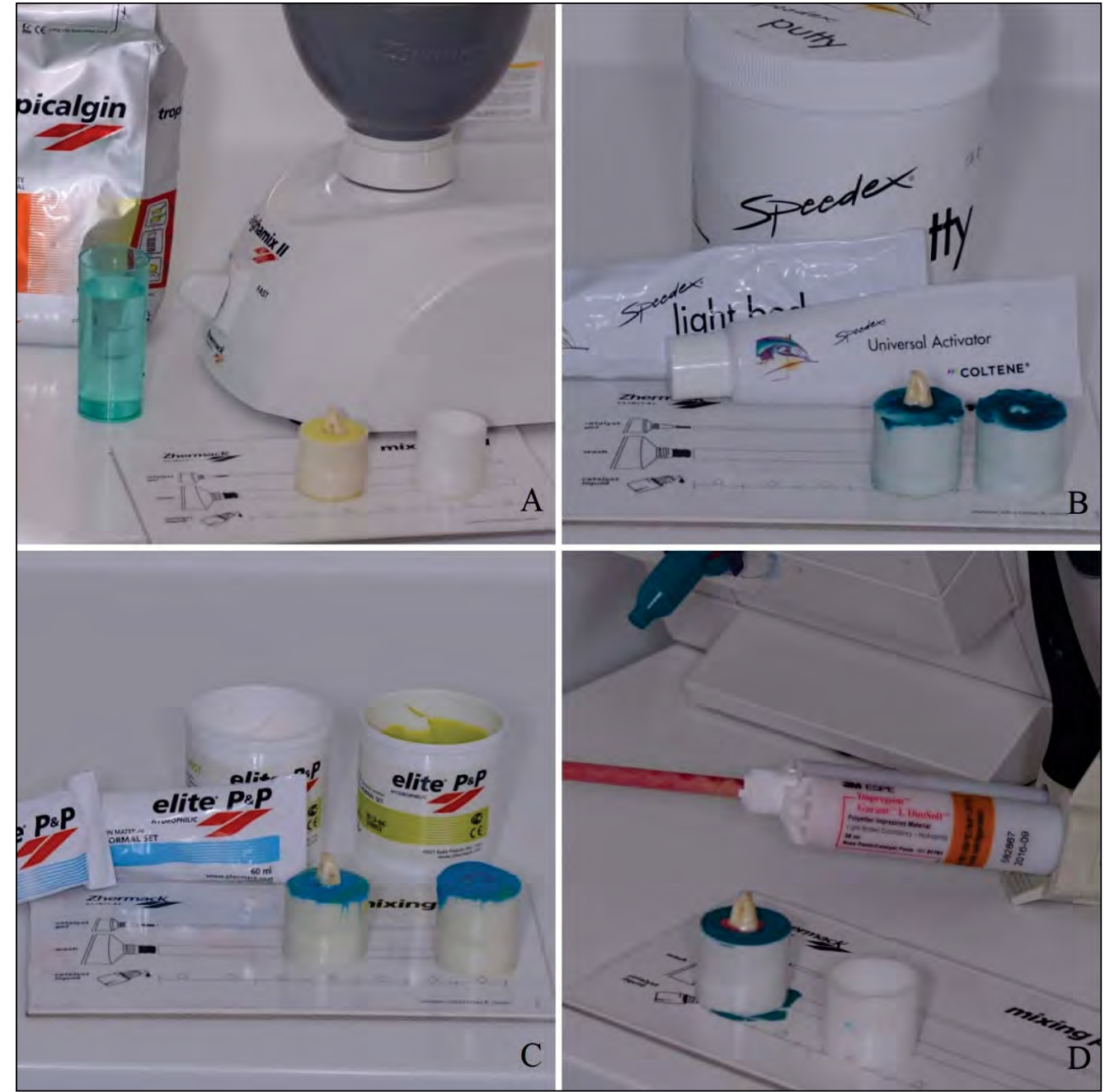

FIGURA 1. Materiale de amprentă utilizate în studiu. A - alginat (Tropicalgin - Zhermack); $B$ - silicon de condensare (Speedex - Coltene); $C$ - silicon de adiţie (Elite - Zhermack);

$D$ - polieter (Impregum-3M/ESPE)

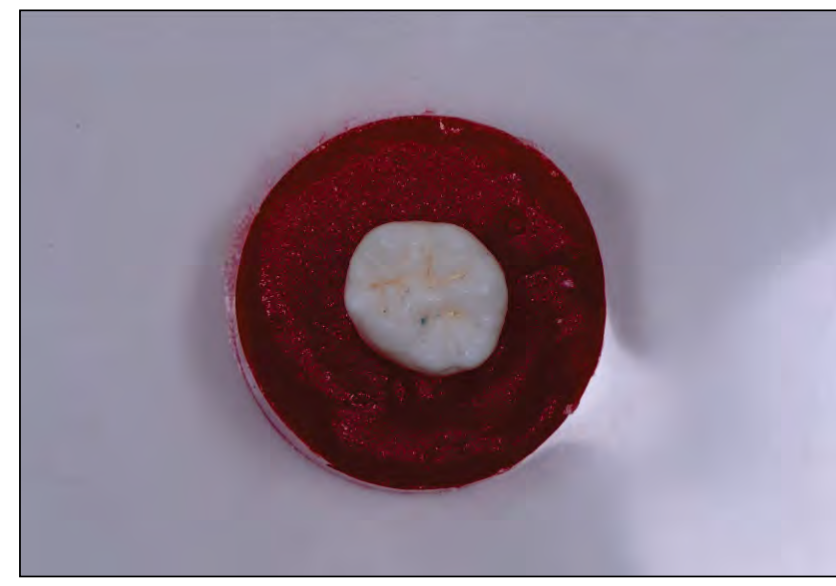

FIGURA 2. Proba martor - suprafaţa ocluzală a molarului de minte extras

\section{REZULTATE}

Rezultatele măsurătorilor pot fi observate în Tabelul 1 şi Tabelul 2.

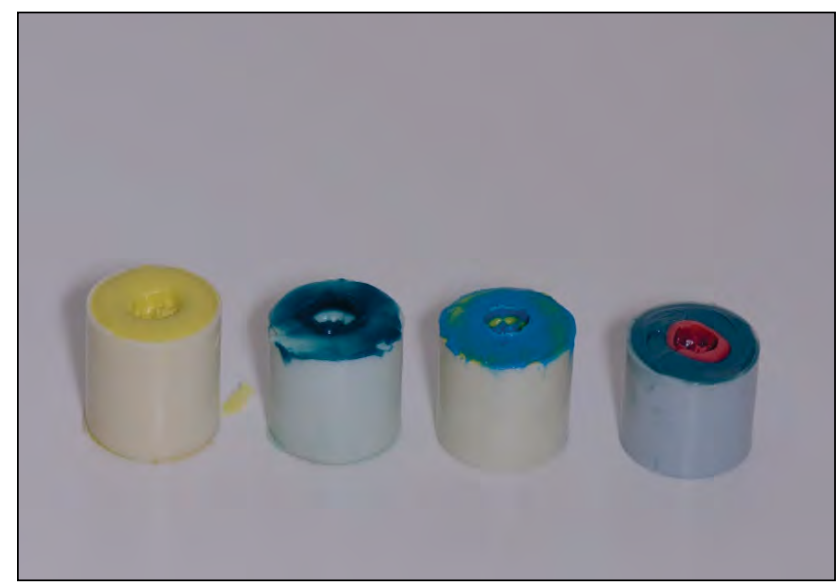

FIGURA 3. Probele analizate - amprente ale suprafeţei ocluzale a probei martor din materialele luate în studiu

Toate materialele luate în studiu au prezentat contracţie de polimerizare. Contracţia maximă are loc în primele 24 de ore pentru toate materialele, urmând ca, după prima zi de la amprentare, acestea 
TABEL 1. Imaginile de stereomicroscopie realizate asupra probelor de investigat

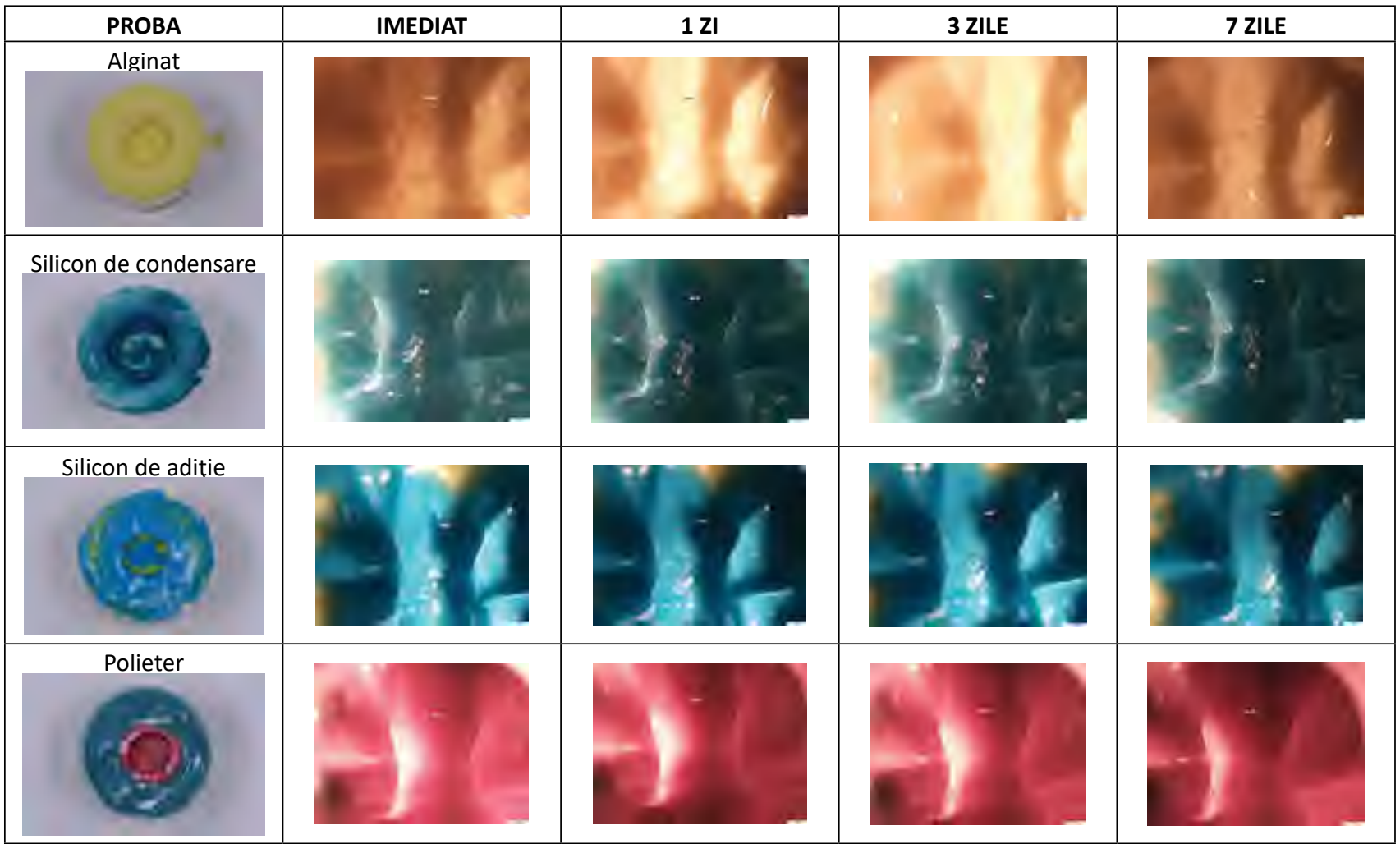

TABEL 2. Rezultatele măsurătorilor obţinute asupra probelor din materialele de amprentă

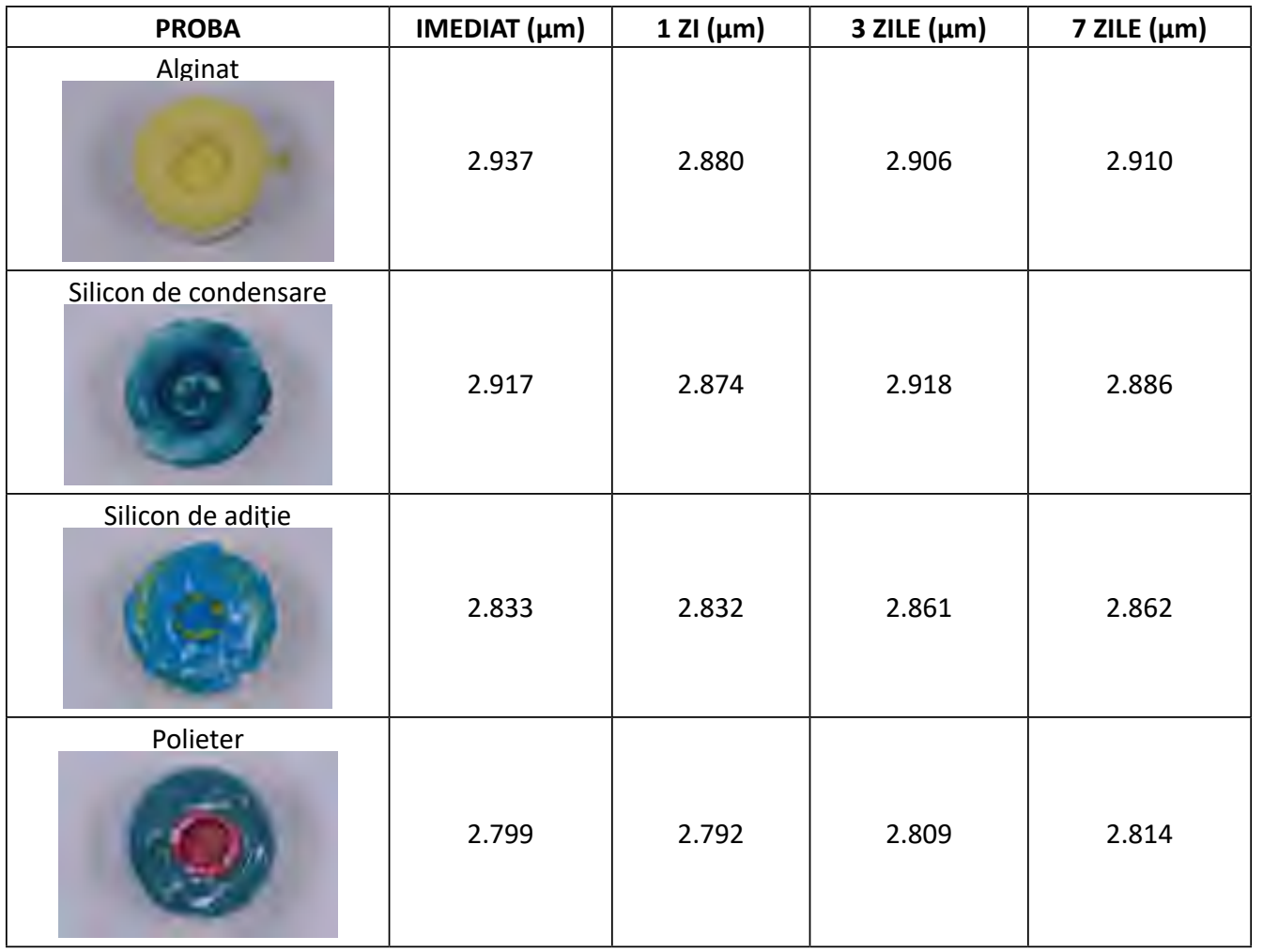

să sufere o uşoară dilatare, probabil datorată detensionării postpolimerizare.

Alginatul suferă o contracţie de polimerizare la 24 de ore de 1,94\%, la 7 zile însă ajungând la doar
0,91\%. Din clasa siliconilor, la 24 de ore se observă o contracţie de $1,47 \%$ a siliconilor de condensare şi de doar $0,03 \%$ a celor de adiţie. Stabilitatea acestora la 7 zile este, de asemenea, superioară alginatu- 


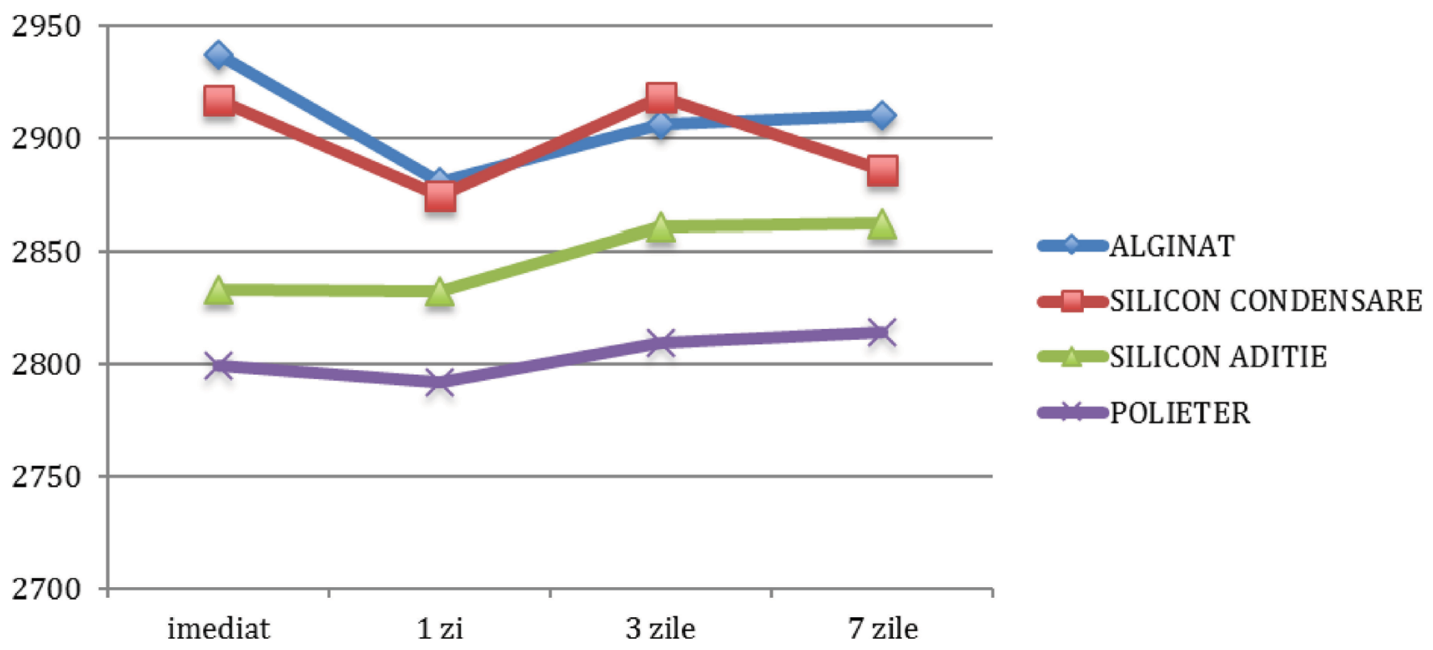

FIGURA 4. Variaţia dimensională a materialelor de amprentă

lui, înregistrând procente de contracţie de doar $1,06 \%$ (silicon de condensare), respectiv $1,02 \%$ dilatare (silicon de adiţie). Polieterii prezintă cea mai mică variaţie în timp, precum şi cea mai mare acurateţe (2.799 $\mu \mathrm{m}$ imediat după amprentare), suferind o contracţie iniţială de $0,25 \%$ şi o dilatare de doar $0,53 \%$ la 7 zile de la amprentare.

Variaţia dimensională a materialelor poate fi observată în Fig. 4.

\section{DISCUŢII}

Materialele de amprentă pot suferi modificări dimensionale după îndepărtarea din cavitatea orală, motivele fiind numeroase: contracţia de polimerizare, eliberarea de substanţe în urma reacţiilor chimice, variaţia termică sau deformări ireversibile în timpul dezinserării amprentei [11]. Prezentul studiu evaluează transformările dimensionale în timp (imediat, după 24 de ore, 3 zile şi 7 zile) ale materialelor de amprentă frecvent folosite în practica stomatologică: alginat, siliconi de condensare, siliconi de adiţie şi polieteri. De asemenea, s-a realizat evaluarea comparativă a fidelităţii materialelor analizate, aspect deosebit de important în realizarea lucrărilor protetice de precizie (coroane, punţi, inlay-uri).

În urma analizei, s-a observat o variaţie dimensională a tuturor materialelor, aceasta însă fiind majoră în cazul alginatului şi minoră în cazul polieterilor şi siliconilor de adiţie. Hidrocoloizii ireversibili, folosiţi frecvent în medicina dentară, sunt predispuşi modificărilor volumetrice, dependente de evaporarea apei şi sinereză $[12,13]$. Apa prezen- tă în alginat există sub formă legată sau liberă, astfel că, prin evaporarea apei libere sau prin imbibiţie în cazul unui mediu saturat cu apă, se produc scăderea, respectiv creşterea volumetrică [13]. În prezentul studiu, s-a observat o reducere a dimensiunilor în primele 24 de ore, urmată însă de o uşoară creştere după 3 zile. La 7 zile de la înregistrarea amprentei însă, scăderea faţă de volumul iniţial este de doar $0,91 \%$. Aceste rezultate sunt în concordanţă cu studiul condus de Rohanian A et al. [14], care indică o turnare a alginatului (Tropicalgin - Zhermack) nu mai târziu de 24 de ore, transformările fiind semnificativ crescute după această perioadă. De asemenea, există studii care indică o fidelitate a alginatului similară hidrocoloizilor reversibili sau chiar siliconilor de adiţie, cu condiţia turnării modelului în primele 15 minute de la înregistrarea amprentei [15]. În practica stomatologică însă, în prezent, acest lucru este deseori dificil de realizat.

Literatura de specialitate recunoaşte superioritatea materialelor elastomerice în comparaţie cu hidrocoloizii ireversibili din punctul de vedere al fidelităţii şi stabilităţii dimensionale [16,17]. Reacţia de priză a siliconilor de condensare constă dintr-un proces de policondensare reticulată a polimerilor de hidroxi-polisiloxani cu tetra-alcoxi-silani catalizată de dilaurat de dibutilitin. Astfel, reacţia de policondensare eliberează alcool, ducând la contracţia materialului [18]. Studiul de faţă confirmă acest lucru, siliconul de condensare înregistrând în primele 24 de ore o contracţie de $1,47 \%$, iar după 7 zile aceasta fiind de doar $1,06 \%$. Se observă astfel modificările dimensionale reduse în comparaţie cu cele ale alginatului, rezultând astfel posibilitatea 
utilizării sale ca material de amprentă cu condiţia turnării imediat după înregistrare. Cu toate acestea, printre dezavantajele sale se numără hidrofobia şi reacţiile alergice provocate de catalizator, precum şi instabilitatea dimensională mai mare decât a siliconilor de adiţie şi a polieterilor $[19,20]$. Aceste limitări contraindică utilizarea lor pentru amprente finale ale lucrărilor protetice de mare finețe.

Siliconii de adiţie, spre deosebire de cei de condensare, eliberează o cantitate foarte redusă de substanţe reziduale în timpul prizei, astfel că stabilitatea dimensională este superioară siliconilor de condensare şi, implicit, hidrocoloizilor ireversibili [21]. Rezultatele prezentului studiu arată faptul că siliconii de adiţie prezintă, în afară de cea mai mică variaţie dimensională la 24 de ore dintre toate materialele, şi cea mai mare acuratețe comparativ cu alginatul și siliconii de condensare. Dimensiunea probei martor $(2.805 \mu \mathrm{m})$ este similară cu cea măsurată imediat după înregistrarea amprentei cu siliconi de adiţie $(2.833 \mu \mathrm{m})$. Studiul lui Vitti RP et al. [22] realizează comparaţia stabilităţii dimensionale dintre doi siliconi de condensare diferiţi şi doi siliconi de adiţie diferiţi, utilizând trei tipuri de tehnici de amprentare (monofazică, bifazică într-un timp şi bifazică în 2 timpi). S-a observat astfel că modelele rezultate prezentau reduceri dimensionale (contracţii) semnificative faţă de modelul de control, acestea fiind însă mai reduse în cazul siliconilor de adiţie. De asemenea, nu s-au observat diferenţe semnificative în funcţie de tehnica de amprentare folosită.

Pe lângă riscul de producere a defectelor de turnare prin eliberarea de hidrogen în timpul prizei, a hidrofobiei, ca dezavantaj al siliconilor de adiţie se găseşte şi inhibiţia prizei produsă de mănuşile de latex $[19,20]$. Cu toate acestea, aceşti siliconi pot fi folosiţi cu succes în amprentarea finală a lucrărilor protetice. Kumar D et al. [23], compară stabilitatea dimensională la turnări repetate a polieterilor şi siliconilor, rezultând superioritatea celor din urmă.

Polieterii prezintă proprietăţi precum stabilitatea dimensională, fidelitatea, caracterul hidrofilic ce determină un unghi de contact redus cu gipsul şi, astfel, o turnare uşoară, devenind un material de amprentă frecvent utilizat în practica stomatologică [24,25]. Rezultatele prezentului studiu arată atât cea mai mică variaţie dimensională la 7 zile, cât şi cea mai mare fidelitate în comparaţie cu siliconii şi hidrocoloizii ireversibili, putând fi utilizat cu succes pentru amprentarea finală. Rigiditatea polieteri- lor este importantă în amprentarea pentru protezele cu sprijin implantar prin facilitarea repoziţionării bonturilor de transfer şi asigurarea rigidităţii portamprentei [26]. Wee [27] compară rezistenţa la torsiune a materialelor de amprentă şi indică polieterii ca având rezultatele superioare celorlalte materiale, susţinând eficienţa polieterilor în amprentarea implanturilor.

$\mathrm{Cu}$ toate acestea, există studii ce atestă superioritatea siliconilor de adiţie faţă de polieteri $[28,29]$. Thongthammachat S et al. [30] evaluează stabilitatea dimensională a diferitelor materiale de amprentă în diferite tipuri de portamprente, turnate la intervale de timp variate. Rezultatele indică necesitatea turnării amprentelor din polieteri o singură dată la interval de maximum 24 de ore de la dezinserare din cauza deformărilor ireversibile în timp ale acestora prin absorbţia apei rezultată în urma prizei gipsului. De asemenea, se indică şi o variaţie dimensională mai redusă a siliconilor de adiţie faţă de polieteri. Astfel superioritatea polieterilor poate fi evidenţiată doar în anumite condiţii: turnare cât mai precoce, depozitare în mediu lipsit de umiditate, manipulare şi dezinserţie atentă.

Studiul de faţă se aliniază acestor rezultate, observându-se o contracţie în 24 de ore de doar $0,03 \%$ a siliconilor de adiţie, cea mai redusă dintre materialele studiate. Polieterii însă prezintă o fidelitate superioară, dimensiunea iniţială $(2.799 \mu \mathrm{m})$ fiind cea mai apropiată de cea a probei martor $(2.805$ $\mu \mathrm{m})$. De asemenea, diferenţa dintre valorile dimensionale iniţiale şi cele la 7 zile este cea mai redusă, datorită rigidităţii lor superioare celorlalte materiale.

\section{CONCLUZII}

Toate materialele de amprentă luate în studiu suferă variaţii dimensionale, contracţia maximă fiind în primele 24 de ore, urmând o uşoară dilatare datorată detensionării postpolimerizare. Siliconii de adiţie prezintă cea mai redusă variaţie volumetrică la 1 zi de la înregistrare, iar polieterii la 7 zile. Cea mai mare acurateţe o prezintă polieterii, în timp ce hidrocoloizii ireversibili prezintă modificări majore ale dimensiunilor şi acurateţe redusă faţă de celelalte materiale.

\section{Notă}

Toţi autorii au contribuit în mod egal la realizarea acestui studiu. 


\section{BIBLIOGRAFIE}

1. Jamshidy L, Mozaffari HR, Faraji P, Sharifi R. Accuracy of the One-Stage and Two-Stage Impression Techniques: A Comparative Analysis. Int J Dent. 2016; 2016:7256496.

2. Pant R, Juszczyk AS, Clark RKF, et al. Long-term dimensional stability and reproduction of surface detail of four polyvinyl siloxane duplicating materials. J Dent. 2008;36:456-461.

3. Kumar RN, Reddy SM, Karthigeyan S, et al. The effect of repeated immersion of gypsum cast in sodium hypochlorite and glutaraldehyde on its physical properties: An in vitro study. J Pharm Bioall Sci. 2012;4:353-357.

4. Nassar U, Oko A, Adeeb S, et al. An in vitro study on the dimensional stability of a vinyl polyether silicone impression material over a prolonged storage period. J Prosthet Dent. 2013;109:172-178.

5. Nicholls Jl. The measurement of distortion: theoretical considerations. J Prosthet Dent. 1977;37:578-86.

6. Alkurt M, Yeşıl Duymus Z, Dedeoglu N. Investigation of the effects of storage time on the dimensional accuracy of impression materials using cone beam computed tomography. J Adv Prosthodont. 2016; 8(5):380-387.

7. Sedda M, Casarotto A, Raustia A, Borracchini A. Effect of storage time on the accuracy of casts made from different irreversible hydrocolloids. J Contemp Dent Pract. 2008;9(4):59-66.

8. Tjan AHL, Whang SB, Tjan AH, Sarkissian R. Clinically oriented evaluation of the accuracy of commonly used impression materials. The Journal of Prosthetic Dentistry. 1986;56(1):4-8.

9. Rosenstiel SF, Land MF, Fujimoto J. Contemporary Fixed Prosthodontics. Mosby, Philadelphia, Pa, USA, 4th edition, 2012.

10. Kulkarni MM, Thombare RU. Dimensional Changes of Alginate Dental Impression Materials-An Invitro Study. J Clin Diagn Res. 2015;9(8):ZC98-ZC102.

11. Shifra L, Guy L, Tamar B, Noga H, Yehuda G, Raphaepilo. Dimensional stability of polyvinyl siloxane impression material reproducing the sulcular area. Dental Materials Journal. 2013;32(1):25-31.

12. Sedda M, Casarotto A, Raustia A, Borracchini A. Effect of storage time on the accuracy of casts made from different irreversible hydrocolloids. J Contemp Dent Pract. 2008;9(4):59-66.

13. Frey $G$, Lu H, Powers J. Effect of mixing methods on mechanical properties of alginate impression materials. J Prosthodont. 2005;14(4):221-25.

14. Rohanian A, Ommati Shabestari G, Zeighami S, Samadi MJ, Shamshiri AR. Effect of storage time of extended-pour and conventional alginate impressions on dimensional accuracy of casts. J Dent (Tehran). 2014;11(6):655-664.

15. Eriksson A, Ockert-Eriksson G, Lockowandt P. Accuracy of irreversible hydrocolloids (alginates) for fixed prosthodontics. A comparison between irreversible hydrocolloid, reversible hydrocolloid, and addition silicone for use in the syringe-tray technique. Eur J Oral Sci. 1998;106(2 Pt 1):651-60.
16. Eames WB, Sieweke JC, Wallace SW, Rogers BL. Elastomeric impression materials: effect of bulk on accuracy. J Prosthet Dent. 1979;41(3):304-307.

17. Lacy AM, Bellman T, Fukui H, Jendresen DM. Time-dependent accuracy of elastomeric impression materials. Part II. Polyether, polysulfides, and polyvinylsiloxanes. J Prosthet Dent. 1981;45(3):329-333.

18. Islamova RM, Dobrynin MV, Ivanov DM, Vlasov AV, Kaganova EV, Grigoryan GV, Kukushkin VY. bis-Nitrile and bis-Dialkylcyanamide Platinum(II) Complexes as Efficient Catalysts for Hydrosilylation Cross-Linking of Siloxane Polymers. Molecules. 2016;21(3):311.

19. Rubel BS. Impression materials: a comparative review of impression materials most commonly used in restorative dentistry. Dent Clin North Am. 2007;51(3):629-42.

20. Gonçalves FS, Popoff DA, Castro CD, Silva GC, Magalhães CS, Moreira AN. Dimensional stability of elastomeric impression materials: A critical review of the literature. Eur J Prosthodont Restor Dent. 2011;19(4):163-6.

21. Johnson GH. Impression materials. In: Craig RG, Powers JM, eds. Restorative Dental Materials. 11th ed. St. Louis, MO: Mosby; 2001:348-368

22. Vitti RP, da Silva MA, Consani RL, Sinhoreti MA. Dimensional accuracy of stone casts made from silicone-based impression materials and three impression techniques. Braz Dent J. 2013;24(5):498-502.

23. Kumar D, Madihalli AU, Reddy KRK, Rastogi N, Pradeep NT. Elastomeric Impression Materials: A Comparison of Accuracy of Multiple Pours. J Contemp Dent Pract. 2011;12(4):272-278.

24. Wassell RW, Barker D, Walls AWG. Crowns and other extra-coronal restorations: impression materials and techniques. Br Dent $\mathrm{J}$. 2002;192:679-690.

25. Craig RG, Powers JM. Impression materials in restorative dental materials. 11. St. Louis: Mosby Inc.; 2002. pp. 330-389.

26. Ceyhan JA, Johnson GH, Lepe X. The effect of tray selection, viscosity of impression material and sequence of pour on the accuracy of dies made from dual arch impressions. $J$ Prosthet Dent. 2003;90:143-149.

27. Wee AG. Comparison of impression materials for direct multi-implant impressions. J Prosthet Dent. 2000;83(3):323-331.

28. Smith PW, Richmond R, McCord JF: The design and use of special trays in prosthodontics: Guidelines to improve clinical effectiveness. Br Dent J. 1999;187:423-426.

29. Pesun IJ, Mayclin T: Troubleshooting vinyl polysiloxane impressions. Northwest Dent. 1999;Jan-Feb:29-32.

30. Thongthammachat S, Moore BK, Barco MT 2nd, Hovijitra S, Brown DT, Andres CJ. Dimensional accuracy of dental casts: influence of tray material, impression material, and time. J Prosthodont. 2002;11(2):98-108. 